\title{
Subverting the Myth of the Submissive Woman in Margaret
}

\section{Atwood's The Penelopiad}

\author{
Alna Maria Mathews Mulloor \\ Stella Maris College (Autonomous) \\ Chennai, Tamil Nadu, India \\ alnamariamathews1998@gmail.com
}

\begin{abstract}
'The Penelopiad' is a retelling of the Greek myth of Odysseus and his faithful wife, Penelope. According to the myth, Penelope cleverly keeps away from more than a hundred suitors when Odysseus went for the Trojan war. Therefore, her character is traditionally associated with marital fidelity and 'The Odyssey' portrays her as the quintessential faithful and submissive wife. This paper proposes to analyse how patriarchy creates the myth of the submissive woman and how Atwood subverts the myth through the characters of Penelope and her twelve maids.
\end{abstract}

Keywords: Myth, Patriarchy, Penelope, Odysseus, Re-Visioning.

Levi Strauss, in "The structural study of myths" talks about the arbitrariness of myths. On one hand, myths seem arbitrary in that they seem to lack logic and anything can happen in a myth. On the other hand, many different cultures present similar myths, a fact which does not fit well with the seemingly arbitrary nature of myths. Myths with similar structure emerge from different cultures which shows the universality of idea and plot. According to the Functionalist School of Thought, every myth must have a reason for its formation. The reason behind most of the myths is the patriarchal setting down of behavioural norms for women. Eve's quest for knowledge is portrayed as her submission to temptation, which led to the fall 
of man from Paradise. According to Greek mythology, the reason for all the problems is Pandora, who opened the box of miseries. Both the Christian and Greek myths portray the first human woman as the perpetrator of evil and misery in the world, which reveals the androcratic leniency of myths.

Carl Jung defines the collective unconscious as a universal phenomenon which is "identical in all men and thus constitutes a common psychic substrate of a supra-personal nature."(Jung 3) The collective unconscious is concerned with universal images that have been existing from the beginning of time. Social conventions and constructs are part of this universal consciousness which seems to have a natural development and imposes itself in each individual's mind. Patriarchy is one such social construct that gets enrooted in everyone's mind. Social conditioning influences people's minds so much so that the boundary between the social convention and the individual conscience becomes blurred.

In The Penelopiad, Penelope says, "So much whispering goes on, in the dark caverns, in the meadows, that sometimes it's hard to know whether the whispering is coming from others or from the inside of your own head." (Atwood 8) This depicts the amount of influence societal norms can have on one's conscience. The mythical Penelope shows deep-rooted patriarchal conditioning which makes her think and act only according to the norms. Atwood's Penelope, even though is submissive to her husband, is seen to possess agency over her thoughts, if not her actions.

Mythology leads to the internalisation of patriarchy even in the minds of women, which results in the subservience of women to patriarchal norms. The more times the myth is retold, the longer it will persist. It gets stamped in the society and moulds the thoughts of the community. This social conditioning creates the need for the re-visioning of myths from the subaltern perspective. According to Adrienne Rich, "We need to know the writing of the past, 
and know it differently than we have ever known it; not to pass on a tradition, but to break its hold over us." (Rich 19)

Only when the patriarchal myth is re-visioned with fresh eyes, will there be chances for re-interpretation and an altered representation of women. The major technique of revisionist writings is the shift from the hegemonic narrator to a subaltern narrator who can narrate the events from the perspective of the oppressed. 'The Odyssey' is narrated by a third person and Odysseus himself, while The Penelopiad, which retells the same story, is narrated by Penelope and the twelve maids who were hanged to death on Odysseus' orders.

The unconscious acceptance of patriarchy as portrayed in the mythology is subverted in Atwood's Penelope, as she narrates her story as a warning to other women. Penelope says, "Don't follow my example, I want to scream in your ears," (Atwood 2) which clearly depicts that the character has realized her flaws and wants to stop the historic plot from being repeated. She retells the story by revealing her innermost thoughts that have not been addressed in any of the myths or classical texts. She says, "it is my turn to do a little storymaking...so I'll spin a thread of my own" which represents her agency over her own life and story.

The hold of patriarchy over women is represented through the character of Odysseus who threatens his wife to remain chaste while he is away, failing which, he would have to kill her. Penelope says that if her chastity is on doubt, "he would have to chop me into little pieces with his sword or hang me from the roof beam", while his promiscuity is widely known. Odysseus is portrayed to be "an excellent raconteur" and Penelope as a good listener to his heroic stories. (Atwood 38) She says that Odysseus considered her ability to appreciate his stories as the most valued virtue in her. Even though the triumphant deeds of Odysseus are narrated to Penelope by Odysseus himself, the story of his narration is narrated by 
Penelope. While Penelope is the listener of his story, Atwood subverts her role into that of the storyteller by giving her the narrative voice.

Adrienne Rich points out that "women have always been seen as waiting: waiting to be asked, waiting for our menses, waiting for men to come home from wars, or from work...or for menopause."(Rich 39) The figure of the idly waiting wife is subverted in the novella as Penelope takes on the duty of managing the castle and estates. Unlike the mythical Penelope, she keeps inventories and directs the spinners and weavers which reveal her oratory and persuasive skills. She stays in another room in the women's quarters after Odysseus leaves which is indicative of her "newly found individuality and freedom."(Akgun 38)

While the traditional Penelope stands as the symbol of modesty, Atwood's Penelope merely pretends to be modest. In the instance where Odysseus asks her if she was willing to come home with him after the wedding, she is said to have pulled down the veil out of modesty; but Atwood's Penelope admits that it was done to hide her laughter. Later, she also accepts that she has occasionally daydreamed about the suitors with who she would rather go to bed. This makes the reader question the virtue of modesty that is being attributed to the mythical heroine.

The frustrated Penelope is seen to rebel against the gods by asking them to cast a dice to decide which mortal's life they are going to ruin just for fun. She is also shown to be attracted more to the darker side and the villains in Hades as she states that "the dark grottoes are more interesting. The conversation there is better if you can find a minor rascal of some sort."(Atwood 14) Penelope's rebellious rage and admiration towards the dark subverts the modesty accredited to her and associates her more to the archetype of Helen, who is considered a rebel. 
Odysseus, on his return, kills the suitors as well as the maids who slept with them as they were considered unfaithful to the kingdom. The Penelpiad throws a different light to this story as they are portrayed to be helping Penelope get secrets from the suitors and were misunderstood by Odysseus. By this, the classical portrayal of the maids as lewd and unfaithful is subverted to give them the impression of faithful martyrs.

The maids narrate ten sections, which are filled with resentment and mockery on the injustice they had to face. The last section of the maids is set in the court of justice of contemporary times on the day of Odysseus' trial. The defence attorney defends Odysseus by saying that he had the right to kill them as they were his slaves. Moreover, the rape is misinterpreted as wilful sex from the maids' part, which represents the corrupt judicial system, which favours patriarchy and power over justice. The judge dismisses the case by saying, "it would be unfortunate if this regrettable but minor incident were allowed to stand as a blot on an otherwise exceedingly distinguished career." (Atwood 147) The lukewarm attitude of the judge is mocked here when the maids call upon the Furies to exact vengeance on their behalf, which is a clear mark that the judiciary has not served them right.

Traditionally in Greek plays, the chorus represents the voice of the society, and the then society was patriarchal. In The Penelopiad, the chorus is sung by the hanged maids, which signifies that the societal voice which was equated to the male voice is subverted to the female voice here. As the chorus is recited to be heard by everyone, the tales of the malignant Odysseus would be heard along with, or even above the glorious tales of him. Towards the end, the maids seek vengeance from the furies and say that they will haunt Odysseus forever. "Hunt him down! Dog his footsteps, on earth or in Hades, wherever he may take refuge, in songs and in plays, in tomes and in theses, in marginal notes and in appendices." (Atwood 148) The mention of songs, plays and marginal notes signify that for every narrative in praise 
of Odysseus, there will be a counter-narrative to condemn him. This exemplifies that revisioning is a counter-narrative to the hegemonic mythological narratives.

Odysseus, after multiple rebirths, is portrayed to be still haunted by the maids who makes him nervous. "They make him nervous. They make him restless. They cause him pain. They make him want to be anywhere and anyone else."(Atwood 152) Odysseus' fear of the maids shows his need to rewrite his past, which is symbolic of the need to rewrite and revision myths from the subaltern or feminine perspective. 


\section{Works Cited}

Akgun, Buket. "The Penelopiad: Dislodging the Myth of Penelope as the Archetype of Faithful and Patient Wife." $4^{\text {th }}$ International IDEA Conference, 15-17 April 2009, Celal Bayar University. Atwood, Margaret. The Penelopiad. Penguin Books, 2005.

Jung, C.G. The Archetypes and the Collective Unconscious. Translated by R.F.C Hull, Princeton University Press, 1969.

Levi-Strauss, Claude. “The Structural Study of Myth.” Journal of American Folklore, vol.68, no.270, 1955, pp 428-444.

Rich, Adrienne. Of Woman Born: Motherhood as Experience and Institution. W.W. Norton \& Company, 1986.

Rich, Adrienne. "When We Dead Awaken: Writing as Re-Vision." College English, vol.34, no.1, 1972, pp 18-30. 